\title{
Breeding and Power in Southeast Asia Horses, Mules and Donkeys in the Longue Durée
}

\author{
William G. Clarence-Smith
}

\section{Introduction: Tibetan Origins}

Horses leap out at the viewer from countless pictures and sculptures in Southeast Asia, and Peter Boomgaard has been a pioneer in developing their neglected history (Boomgaard 2004, 2007a). Horses clearly belong to the longue durée in Southeast Asian history, for they have been present for at least two millennia, linked structurally to war and elevated social status. In contrast, mules, the sterile offspring of horse and donkey, are hidden from view. They came later, spread less, and were employed for more humble pursuits. As for donkeys, they have been almost absent from the region (Clarence-Smith 2004b).

Horses are commonly assumed to have come from India and China. ${ }^{1}$ Southeast Asian elites certainly absorbed much equestrian lore from these neighbouring civilizations. ${ }^{2}$ India was also the probable source of prejudices against donkeys and mules (Kipling 1921:76-77, 203-205). For the animals themselves, however, archaeological analyses of equine bones are rare, and there are no DNA surveys. Linguistic evidence is tricky, while iconic, epigraphic and documentary records are sparse and fragmentary (Blench 2010; Wade 2009b).

Sifting through what evidence there is, Tibet appears to be the most likely origin of most Southeast Asian ponies, defined as horses measuring under 14 and a half hands ( 1.47 metres) at the withers (shoulders). These ponies entered the region via Yunnan, at a time when it was independent of China. However, they probably came ultimately from the equine corridor of eastern Tibet, with its cool dry climate and natural pastures. In contrast, grasslands in Southeast Asia and Yunnan were usually deliberately created and maintained by periodically firing vegetation. ${ }^{3}$

Horses may have emerged in Tibet in the second millennium все, at the same time as they entered China from the Eurasian steppe. They were certainly present by the first millennium BCE (Blench 2010:2; Bagley 2001:39). According

1 Boers (2007:52); Hoekstra (1948:39-40); Charney (2004:174).

2 Crawfurd (1971:154); Quaritch Wales (1952); Charney (2004:164).

3 Henley (2005a:8-9, 544-545); Reid (1988:118); Chapter 2 in this collection.

(C) WILLIAM G. CLARENCE-SMITH, 2015 | DOI 10.1163/9789004288058_004 
to one account, Tibetan ponies developed as half a dozen tough and surefooted breeds, distinct from those of Mongolia, as natural or social selection encouraged adaptation to harsh conditions at high altitude. ${ }^{4}$ As Tibetan ponies are smaller and less corpulent than those of Mongolia, an infusion of blood from across the Himalayas has been suggested (Kidd 1985:38, 47, 191).

The Chinese obtained Tibetan horses from early times (Bøckman 1991:177; Schafer 1985:62, 64-65, 76). The Qin, one of China's 'warring dynasties', expanded into the Tibetan borderlands of Sichuan in the fourth century BCE, partly to obtain such horses (Bagley 2001:39). Since then, the country of Kham, the south eastern Tibetan marches, has often been annexed to Sichuan, leading authors to refer to the 'wiry pony of Szechwan' (Schafer 1985:62). In reality, the great rice-growing bowl of Sichuan proper is not a land of equids (Gill 1883:88, 107; Davies 1909:222, 292-294).

Tibetan ponies probably diffused onto the limestone plateau of Yunnan, where archaeological evidence suggests that they were raised from the sixth century BCE (Wade 2009b:162). Dian bronzes from the independent state of the region, dating from around the second century BCE onwards, show horses ridden without stirrups. Han China obtained Dian horses as gifts and tribute, or through raids (Pirazzoli-t'Serstevens 1974:19-20). The later Nan Zhao kingdom continued to supply ponies to China from the late sixth century $\mathrm{CE}$ (Backus 1981:9, 30, 119). To be sure, the Chinese long preferred sturdier and larger Mongolian ponies to Tibetan 'river ponies' so called because they were shipped down the Yangzi (Coates 1994, 22-24, 59, 186). However, ponies from the south-western marches were a significant resource, especially when the steppe turned hostile to the ruling dynasty in China. ${ }^{5}$

\section{The Diffusion of Tibetan Ponies across Mainland Southeast Asia}

Ponies moved easily from Yunnan into the northern uplands of Southeast Asia (Luce 1960:326; Forbes and Henley 1997:83). Indeed, there were no ecological barriers, and a mosaic of Burmic, Tai, Austroasiatic, and Miao-Yao peoples lived on either side of the current border with China (Backus 1981). In the ninth century CE, horse breeding was especially developed in what are today western Yunnan and northern Burma (Wade 2009b:166-167; Luce 1960:326).

Archaeological evidence suggests that horses were being bred, and copied in figurines, on the Khorat Plateau of northeastern Thailand between 500 BCE

4 Peissel (2000:82-83, 127-130, 184, 235-241).

5 Backus (1981:163); Paul Smith (1991); Yang (2004:297-299). 
and 400 CE (Wade 20ogb:162). Horse breeding spread easily into Southeast Asia's Dry Zone, where a rain shadow effect lowers annual precipitation. Open savannahs provided rough grazing, extending over a discontinuous belt of plains and low plateaus from central Burma, to northeastern Thailand, Cambodia, and south-central Vietnam (Fukui 1999). Local fodder crops, such as sorghum in central Burma, were also well adapted for horses (Charney 2004:172).

Trade with India and China is unlikely to have had much effect on the bloodlines of Southeast Asia. The balance of equine trade always appears to have been in Southeast Asia's favour. For example, China obtained Yunnanese horses via northern Vietnam in the first millennium CE (Yang 2004:295-296). Even when horses moved the other way, they mainly consisted of a kind of Tibetan pony, as in the case of northeastern India. ${ }^{6} \mathrm{~A}$ smaller version of the Tibetan pony also prevailed south of the Yangzi in China (Mundy 1919:III-1, 266, n.4; Moor 1968:189).

The hypothesis of a Tibetan origin for the great majority of horses in Mainland Southeast Asia is reinforced by morphological considerations. Although ponies naturally tend to become smaller and 'weedier' in hot lowland zones, they continue to display marked physical affinities across the whole region (Moor 1968:189). That said, DNA tests would be necessary to resolve scientifically the question of how populations relate to one another.

\section{The Mule Frontier}

The common small grey donkey, coming either from the steppe or from India, was ubiquitous in Tibet by the end of the nineteenth century, being raised by most farmers and herders (Bell 1998:44; Legendre 1913:194). Tibet also had larger donkeys, however, some of which were sent to the Chinese court as a gift as early as $654 \mathrm{CE}$. Mules were reported to be present in Tibet shortly thereafter (Schafer 1985:8, 76). In modern times, Tibetan riding mules were considerably larger than pack mules, reflecting the existence of large breeding donkeys, possibly imported from North China. ${ }^{7}$

Mules and donkeys followed horses onto the Yunnan Plateau from Tibet at an uncertain date, but the Mongol annexation of Yunnan, in the midthirteenth century CE, probably gave mule breeding a boost. The Mongols

6 Chakravarti (2009:156-157); Joshi and Brown (1987:308); Chandola (1987:76); Balfour (1871, II:613); Kipling (1921:181).

7 Teichman (1922:101, 221-222, Plate LXII). 
garrisoned their newly conquered province with Inner Asian Muslims, who gradually evolved into Mandarin-speaking Hui communities, renowned for their mule breeding skills. ${ }^{8}$ Mules were certainly common on the Yunnan Plateau by the late nineteenth century, and donkeys were present on a small scale (Pourias 1889:16). However, breeding hardly spread at all into Southeast Asia. ${ }^{9}$

Mules were more widely employed in Mainland Southeast Asia, as they plodded along the lengthy trails of the 'southern silk road'. These routes went back to the second century BCE, although human porters initially carried goods (Pirazzoli-t'Serstevens 1974:45, 63). Mules may have been employed in caravans by the sixth century (Giersch 2006:170-171, 174-179). They certainly travelled on Tibetan routes in the eighth century (Schafer 1985:8).

By the late nineteenth century, mules dominated the booming caravan traffic, with an average of five or six mules to one pony (A. Forbes 1987:28). Yunnanese muleteers, especially Muslim Hui, developed a spider's web of routes, radiating out in all directions from three main entrepôts in Yunnan. Most termini were river ports, although caravans followed the un-navigable Salween to the sea at Moulmein. The muleteers also shifted bulky goods to yaks on the edges of the high Tibetan Plateau (A. Hill 1998; Forbes and Henley 1997:79-89).

Southeast Asian dependence on imports of mules from Yunnan and Tibet persisted (Clarence-Smith 2004b; Younghusband 1995:77-78). Burma appeared as an exporter to British India and Malaya in colonial times, but these were reexports of Tibetan and Yunnanese equids (Courtellemont 1904:173-179, 242). The reluctance of most Southeast Asians to engage in mule breeding themselves remains to be explained.

\section{The Spread of Horses in Maritime Southeast Asia}

The same broad type of pony can be found all across Southeast Asia, as far as Timor. ${ }^{10}$ As dates of introduction are later than for the mainland, this suggests that the equine stock of the islands came mostly from the mainland, and was moved in short 'island-hopping' trips on small boats.

The famous sculptures in the temple of Borobodur in south-central Java, which date from the eighth and ninth centuries $\mathrm{CE}$, seem to portray real local

\footnotetext{
8 Forbes and Henley (1997:29-31, 38, 53, 79); Wang (1996:76, 117-125, 156).

9 Scott and Hardiman (1900-01, II:1, 200-202, 205, II-2, 68); Younghusband (1995:77-78); Nguyen (1965:141).

10 Moor (1968:189-190); Goodall (1973:167-168, 177-181); Kidd (1985:193).
} 
ponies, rather than idealized Indic types (Wade 2009b:167). Some horses may already have been in Java in the seventh century, but the evidence is equivocal (Knapen 2001:294; Burkill 1966, I:1216). By the thirteenth century, 'hill ponies' were employed for riding inland in Java (Chao Ju Kua 1911:77).

A veritable 'cowboy country' developed in Nusa Tenggara (the Lesser Sunda Islands), an archipelago that becomes increasingly dry as it approaches Australia, and has the highest concentrations of horses in Southeast Asia. Epigraphic evidence shows that they were bred in Bali by the tenth century (Lombard 1967:89; Atmodjo 1985:31-32, 48). Evidence from bones has them present in the island of Timor by about the fifteenth century.11

In other parts of Maritime Southeast Asia, horses only spread after Europeans had arrived, but they were of the local type. Archaeologists have excavated no horse bones before the Spanish conquest of the Visayas in the late sixteenth century (Nishimura 1999:35). Nor is there any evidence for their presence, there or in Luzon, in other sources. ${ }^{12}$ Moreover, words for horse in the languages of these parts of the archipelago derive from Spanish or Portuguese (Crawfurd 1971:154; W. Forbes 1976:16). Sulawesi was a similar case. ${ }^{13}$ Nevertheless, Europeans imported ponies from neighbouring islands, or from the mainland, and not from further afield (Wernstedt and Spencer 1967:211).

Abundant exports of ponies from the eastern archipelago contrast with the failure of Mainland Southeast Asia to become self-sufficient. In the early sixteenth century already, Bali, Lombok and Sumbawa were supplying Java with numerous horses (Pires 1944, I:202-203). By the nineteenth century, Nusa Tenggara and South Sulawesi exported many ponies, not only to Java, but even to Mauritius in the western Indian Ocean. ${ }^{14}$ The Philippines developed separate patterns of horse exports, to south-eastern India in the eighteenth century, and to south-eastern China in the nineteenth century (Quiason 1966:73, 105; Coates 1994:15-16, 29).

The northern half of Sumatra was another exporter, albeit on a smaller scale. There may have been horses here already in the third century CE, although the identification of place names is problematic (Chakravarti 1999:205). By the twelfth century, Chinese texts suggest that exports had begun (Chao Ju Kua 1911:72; Wade 2009b:170). The mountainous northern half of the island certainly developed a vigorous equine complex over time (Boomgaard 2004:213-216).

\footnotetext{
11 Ramos and Rodrigues (1980); Ian Glover, personal communication, 2004.

12 Pires (1944, I:133-134); Balfour (1971, II:614); Junker (1999:327).

13 Pelras (1996:78-79, 99-100); Henley (2005a:69); Crawfurd (1971:277).

14 Parimartha (1995:137-138); Clarence-Smith (2002, 2004a:57-64).
} 
In the seventeenth century, Aceh sent 'small, yet sprightly' ponies to southeastern India (Lombard 1967:89, 110, 221; Ito 1984:378). In the nineteenth century, 'Batak' and 'Achin' ponies crossed the straits to the towns of the Malayan Peninsula (Balfour 1871:613; Kreemer 1922-23, I:512-513).

There were limits to the penetration of horses into Maritime Southeast Asia, even after the Europeans had arrived, with ponies absent from certain apparently suitable uplands. Notable examples were the interior of the Malay Peninsula, the southern half of Sumatra's Barisan range, and the stupendous mountains of New Guinea. Most of the vast Borneo plateau was similarly void of horses, albeit with minor exceptions (Moor 1968:190).

\section{Long-distance Maritime Imports and Exports}

A few horses were brought by sea over long distances, from the first millennium CE onwards, notably as gifts from Chinese emperors to loyal tributaries. Southeast Asian envoys to China in the seventh century specifically requested horses. Although it is not clear whether such requests were always heeded, Champa received fairly regular presents of horses from Song emperors from the late tenth century (Wade 2009b:165-168; Burkill 1966, I:1216).

However, exports of horses from China to Southeast Asia were tightly controlled. In 1175, officials of the central court upbraided a Fujianese trader for promising to sell horses to Champa, as 'China's horses have never been permitted to be sent beyond the borders' (Wade 2oogb:169). Chronically unable to obtain sufficient horses to meet the empire's needs, China did not wish to send large numbers to 'southern barbarians'. Moreover, horses could not easily be smuggled unnoticed onto a junk.

The flow of horses went mainly in the opposite direction, as tribute to China. Vietnam and Yunnan were amongst such tributaries from early in the first millennium CE. After the Ming dynasty had seized power in 1368, it faced the hostility of the steppe. Horses then came to China more regularly from all over Southeast Asia, in small numbers by sea, and in larger numbers overland (Ptak 1991; Wade 2009b:168, 173-174).

India was also chronically short of horses, and thus sent no more than a trickle to Southeast Asia. As early as the third century CE, horses from India may have reached the Straits of Melaka and Cambodia, although the destination could equally have been Tamilnadu. ${ }^{15}$ The traffic to Southeast Asia was

15 Chakravarti (1999:205, 2009:151-152); Wade (2009b:164-165). 
occasional, with no large numbers ever dispatched, and it was more than counter-balanced by Southeast Asian ponies entering southern India. ${ }^{16}$

With the arrival of Europeans in the sixteenth century, potential new sources of imports opened up, but with few practical results. Portuguese officials, wishing to befriend Southeast Asian rulers, occasionally gave them fine horses, some of which were described as European (Lombard 1967:228-229). However, the Portuguese were more likely to donate Arabs and Persians, of which they shipped large numbers to India (Loureiro 2009). The Dutch voc also initially conferred Arabs and Persians on its protégés, before cutting costs by breeding horses on islands off the north coast of Sri Lanka (Boomgaard 2004:212-213).

The Spaniards hardly had a greater impact. Very few horses came from New Spain, as it was so difficult to keep them alive crossing the vast Pacific Ocean (Diaz-Trechuelo 1963:203). Ponies from China and Japan were more significant, as the Spaniards found ways of eluding prohibitions on exports. In any event, the standard Southeast Asian pony soon prevailed, possibly obtained from the Muslim foe in Mindanao and Sulu (Bankoff 2007a:85, 191).

The embryonic nature of mule breeding in the Philippines was perplexing, as the Spaniards transformed the economy of the Americas with these animals. They brought a few donkeys and mules from New Spain, but with no significant impact (Diaz-Trechuelo 1963:203). China was more important as a source of donkeys and mules, but again with no apparent effect on local breeding (Blair and Robertson 1903-07:xvi, 90, 180).

A similar lack of donkeys and mules characterized the rest of Maritime Southeast Asia, even though a word for donkey was generally known (Crawfurd 1971:25). Donkeys appeared occasionally in Indonesia, but as oddities. They were reportedly in a royal procession of 1359 in Java, in the company of camels, perhaps imported to demonstrate royal power (Robson 1995:68, 128). In Batavia in 1709, 'a train of slave women on donkeys' followed Abraham van Riebeeck, the Dutch governor-general, in a similar manifestation of authority (J. Taylor 1983:57).

New Breeds in Southeast Asia to c. 1800

The genetic consequences of even quite small amounts of new blood could have been major. Deliveries of horses from China probably consisted of Tibetan 
and Mongolian ponies, although 'divine' Central Asian horses of Fergana may have reached favourite allies. Ships would also have brought tough Indian crossbreeds from Kutch and Sind, fine Arabians, and large Türkmen (Turcomans) from Persia. Western stock, whether from Europe or the Americas, was rare.

In reality, it is difficult to detect much impact from this outside blood on the ponies of Mainland Southeast Asia, because larger and 'finer' horses acclimatized badly in tropical conditions. Early modern Thai kings made sustained efforts to obtain Middle Eastern horses, and, failing that, horses from Java, but there is no indication that this led to self-reproducing new breeds (Pombejra 2007). Less is known about Burma, Cambodia or Vietnam, but again, no new type of horse can be seen to have emerged.

In Maritime Southeast Asia, new breeds did appear, of which the largest was the Priangan (Preanger) horse of western Java. It emerged from the late seventeenth century, as a result of crossbreeding with Middle Eastern horses, a process that was actively encouraged by the Dutch from 1736 (Boomgaard 2004:218-219, 223). As Arabs are small, only just qualifying as horses rather than ponies, the Persians were probably of the big bony Türkmen type. By the 189os, Priangan horses might reach 15 hands, but they had weak bones and were 'razor-chested' (Worsfold 1893:220). Although this was the tallest local horse in Southeast Asia, one observer thought that it 'otherwise cannot be highly praised' (Cabaton 1911:119). Moreover, the Priangan horses tended not to breed true (Barwegen 2005:46-47; Sibinga Mulder 1927:321).

The Kedu horse of south-central Java was quite different, as it was the result of careful selection within local equine stocks by Javanese aristocrats from the early eighteenth century (Boomgaard 2004:220). Though smaller than the Priangan horse, it was much better proportioned (Cabaton 1911:120; Barwegen 2005:47). One specialist of the 1930 s was bowled over by the beauty of this 'miniature horse' (Kay 1939:24-25).

The most famous Maritime Southeast Asian breed was the Sandalwood, which probably emerged in early modern times. Variously said to originate in Sumbawa or Sumba, it was known as 'the handsomest and best breed' and 'the Arab of the archipelago.' ${ }^{17}$ In accordance with this sobriquet, it has been alleged that there must have been Arab blood in its veins (Kidd 1985:193). There is no hard evidence to substantiate this view, however, and selective breeding may have been more important for its development. 


\section{Horses and Southeast Asian State Formation}

A connection between horses and political power emerged, in part because of the speedy communications that these animals afforded. Mounted units also made armies more mobile, and cavalrymen were a particularly formidable force on the battlefield before the rise of firearms. Even after the introduction of firearms, cavalry continued to play an important role in scouting, foraging, flanking, probing, and the pursuit of fugitives (Boomgaard 2004, 2007a; Charney 2004:Ch. 7).

It is thus unsurprising that Southeast Asia's earliest large states often had capital cities located close to supplies of horses, as in Burma. The capital of Pagan, which flourished from the ninth to the thirteenth century CE, was in a dry area, with good access to horses. The Chinese customs official Zhao Rugua (Chao Ju-kua), who compiled information about the twelfth and early thirteenth centuries, reported on 'a great plenty of horses', ridden without a saddle (Chao Ju Kua 1911:58). Of 185 mentions of animals in Pagan inscriptions known to scholars around 1940, 15 referred to horses (Luce 1960:370, 373-375). Tomé Pires (1944, I:102, 111), in the early sixteenth century stressed the importance of both horses and elephants to the power of the successor state of Ava, whereas he noted only elephants for the rival state of Pegu to the south.

Place names further indicate that specialized horse breeding areas extended from the city of Pagan eastwards to Kyaukse (Frasch 1996:180). Indeed, the uplands of the northern Pegu Yoma range, especially the slopes of mystical Mount Popa, long remained famous for raising legendary horses (Scott and Hardiman 1900-1901, II:2, 263).

As many historians have noted, the capital of the great empire of Angkor, which flourished from the ninth to the fourteenth century, was not located directly in the 'rice bowl' of Battambang. Carvings show many horses, ridden without stirrups, as well as elephants. ${ }^{18}$ Inscriptions also refer to horses (Quaritch Wales 1952:88). That said, Zhou Daguan (Chou Ta-kuan), a Chinese envoy in Angkor in 1296, stated that these horses were 'very small' (Chou 1967:35).

The confederation of Champa, in what is today central Vietnam, had few rice fields, but disposed of numerous horses, as well as elephants (Wade 20ogb:165). Champa may have bred the smallest horses in all of Southeast Asia, for Ma Huan declared them to be as small as donkeys (Ma Huan 1970:81). Nevertheless, they were plentiful, for Tomé Pires (1944, I:113) noted of the Cham 
in the early sixteenth century that 'they all have horses'. Indeed, by the late eighteenth century, horses were running almost wild in the mountains of what is today south-central Vietnam (Li and Reid 1993:125).

The Vietnamese of the Red River, blessed with rice, horses and elephants, developed a precocious horse culture, based in part on easy access to Yunnanese horses (Yang 2004:295-296). China ruled this area from 111 BCE to $939 \mathrm{CE}$, integrating it into a civilization where equids were part of daily life. Vietnamese tombs of the Han era contain model farms, made of ceramics, with horses among the domestic stock (K. Taylor 1983:50; K. Hall 1992:263). In the midninth century, mountain chiefs from the fringes of the Yunnan Plateau bartered horses and cattle for lowland salt. When a senior Chinese official took control of salt producing villages and altered the terms of trade, the inhabitants called on Nan Zhao for redress. ${ }^{19}$ In early modern times, northern Vietnam was described as 'a land of many horses', with breeding an upland speciality (Pires 1944, I:115; Nguyen 1965:141-142).

The relation between horses and centralized states may have been greatest in Java, where elephants were not present in the wild, though a few were imported by sea. While states of the 'Malay World' often rested on the control of sea-lanes, this was less true of densely populated Java, where cavalry was crucial to political centralization (Quaritch Wales 1952:59-61; Pires 1944, I:193, 227). The capital of Majapahit was situated close to the numerous horses that Tomé Pires (1944, I:198) reported as grazing in the eastern part of the island.

The adoption of firearms from the fifteenth century had a somewhat contradictory impact on horse-borne warfare. Capital cities were often moved to seaports, where the new weapons could most easily be imported. However, firearms also made horses more useful than elephants, as the latter presented easier targets and tended to panic in the din of battle (Charney 2004:16o-163, 183-185).

The spread of new Abrahamic faiths may also have contributed to raising the profile of horses. For Muslims, they were unquestionably noble beasts, whereas elephants had a somewhat troubled reputation, having been employed to attack the Prophet. Elephants were certainly part of Muslim royal courts and armies in South and Southeast Asia, but they tended to make way for horses over time (Clarence-Smith 2004c). Christians found elephants strange and hard to handle, rather than religiously tainted, while sharing the Muslims' enthusiasm for horses.

19 K. Taylor (1983:239-240); K. Hall (1992:266); Wade (2009b:169). 


\section{Modern Western Colonialism and Horse Breeding}

The modern Western colonial occupation of Asia and Africa depended greatly on equids in military terms. 'Flying columns' consisted of dismantled mountain and machine guns on the backs of ponies or mules, squadrons of light cavalry, and a mounted baggage train able to keep up with the first two forces (Callwell 1990).

Colonial officers and officials, imbued with notions of Western scientific superiority, thus sought to transform the breeding of Southeast Asian horses, but they met with almost complete failure. Imported horses refused to eat local fodder, reproduced poorly, and died quickly, and their crossbred progeny suffered from similar defects. Moreover, they were subject to the dwarfing that occurs naturally among horses in tropical conditions (Bankoff 2007b:105-106, 109-111). One particular problem in Southeast Asia was that bamboo was a significant fodder, which imported stock would not eat (Younghusband 1995:76, 144; Rémond and Winter 1944:29).

The Spaniards imported Arab stallions into the Philippines in 1858 , to produce artillery horses, but they actually died of starvation, due to a lack of suitable fodder (Bankoff 2007b:108-111). Nor did the Americans do much better with imports of American and Australian breeding stock, because of a combination of disease and feeding problems (Elliott 1968:346; Foreman 1906: 336-337).

Although the French claimed more success in Indochina, this is open to doubt. Over two generations, Syrian Arabs and Tunisian Barbs were crossed to produce horses that were three quarters local by blood, slightly larger, and allegedly retaining the endurance and resistance of local animals (Teston and Percheron 1931:916-917, 919). However, the British judgement was that French crossbreeding since the end of the nineteenth century had failed, including attempts with horses imported from Java and Burma (Indo-China 1943:288289). Nor were efforts with Australian imports in neighbouring Thailand crowned with any greater success (Thompson 1941:332).

Cultural misunderstandings also occurred, for example in the Chin area of Burma. Local people refused to have their mares serviced by a prize stallion provided free by the Frontier Force. They explained to a perplexed British official that they were inexpert riders, and that they were 'not keen to produce a stronger and more fiercely intractable breed' (Stevenson 1970:60).

Colonial efforts in the Malay world fared no better. The British in Penang mated Arab or Persian stallions with Sumatran mares around 1830, but soon gave up these experiments (Burkill 1966:1217). The Dutch were scarred by the Java War, as the metropolitan government had decided to abolish cavalry and 
horsed artillery in 1825 , just as the island was about to explode into a destructive rebellion that lasted till 1830 . An initial shortage of horses nearly resulted in disaster for Dutch arms (Heshusius 1978:8-11). A pre-existing stud in Priangan was thus reactivated (Payen 1988:100). Persians, Arabs and Sandalwoods were then crossbred with local mares throughout the nineteenth century, with Australian Walers added in the 1920s. However, results were disappointing (Barwegen 2005:44-45). Indeed, attempts by officers and racing enthusiasts to breed large horses were criticized as a waste of money, which would have been better spent importing ponies from Nusa Tenggara. Small horses were normal in the tropics, it was argued, and it was pointless to struggle against nature (Sibinga Mulder 1927:321-322).

Persistent efforts to 'improve' the horses of Nusa Tenggara itself, with imported Arab and Australian stock, accomplished little. That said, private initiatives on the part of Hadhrami Arab horse traders and local rajas seem to have been somewhat more effective than those undertaken by government studs. ${ }^{20}$

Incapable of changing Southeast Asian horses much, racing enthusiasts and governments fell back on importing Australian Walers. These fine horses, bred in a semi-tropical climate, were sold from South Africa to Japan by the end of the nineteenth century. By 1941, almost all the horses required for military, police, and parade duties in Southeast Asia were Walers, as well as those dominating race-tracks and polo grounds (Yarwood 1989). Local ponies were left with the drudgery of transport work, and occasional participation in agricultural tasks.

\section{Modern Western Colonialism and Mule Breeding}

Colonial powers were no more successful in enhancing mule breeding. The Dutch were the most refractory to the possibility, having no significant experience of these hybrids at home, and only minor exposure to them in their Caribbean colonies. Despite the appearance of donkeys in Java in 1709, as noted above, there are no indications that the Dutch ever thought of fostering the breeding of mules in Indonesia.

Iberians had the necessary skills and inclinations, and yet proved unable to act. A proposal to import Spanish mules for the armed forces of the Philippines,

20 Clarence-Smith (2002); Parimartha (1995:206); Patji (1991:165); Ormeling (1956:115); Hoekstra (1948:45-46); Sibinga Mulder (1927:323-324); Wielenga (1926:16, 35-36). 
in 1883, reflected a failure to breed them locally (Bankoff 2007b:109). In that decade, John Foreman encountered a grand total of five donkeys in his peregrinations around the Philippines (Foreman 1890:388). The Portuguese, who shared a common mule culture with the Spaniards, never even seem to have tried to raise mules in East Timor.

The American victors of 1898 in the Philippines were probably the world's greatest mule breeders at the time, but they did no better than their Spanish predecessors. The Americans brought numerous military mules to the Philippines, at great expense, and therefore imported 10 jack (male) donkeys in 1904 to breed mules locally in the government's experimental stock farms (Montemayor 1952:279). Private companies sought to do likewise. ${ }^{21}$ As none of these initiatives came to fruition, infantry officers concluded in 1927 that it would be better to recruit 'native ponies' as pack animals, rather than to import the 'time-honored Army mule' from America. ${ }^{22}$

The French, heirs to a similar glorious tradition of mule breeding, achieved even less in Indochina. They also imported many mules, to impose their rule in the mountains of northern Indochina, obtaining them from China, Algeria and France (Teston and Percheron 1931:914). Despite their military reliance on these animals, notably to transport mountain guns, they did not develop the embryonic Vietnamese breeding sector in their colony.

The British had little experience of mules at home, but they had built up some credentials in the Punjab in northwestern India, and had high hopes for Burma, after its final conquest in the 1880s. The Army of India's mountain batteries suffered from a chronic deficit of mules, which had to be filled by expensive imports from Argentina, the United States, and elsewhere (Tegetmeier and Sutherland 1895:135-137). Persian jack (male) donkeys were therefore provided free for stud purposes in the southern Shan States of Burma. However, for reasons that are not stated, 'mule-breeding did not prove popular'. ${ }^{23}$

Malaya was not a target of British mule breeding aspirations, although mules were present. They were reportedly employed before 1917 to transport tin ore from an inland mine in Pahang, Malaya (Ledesma et al. 1997:134). An Indian mule battery, stationed in Singapore, mutinied in 1915 (Dijk 2009:124). Such mules were almost certainly imported from China and India respectively.

21 NARA, RG 350 (Bureau of Insular Affairs), 1914-45, Box 272, 1214-54, No. 3081, 'I.X.L. Cattle Co. Inc.', 7 December 1923.

22 NARA, RG $35^{\circ}$ (Bureau of Insular Affairs), 1914-45, Box 422, 2392-149, War Department, Note, 1 June 1927.

23 Imperial Gazetteer 1907-1909:xxii, 258. 
A shortage of mares would have inhibited local mule breeding, even if Pashtun (Pathan) immigrants might have introduced donkeys into Kelantan. ${ }^{24}$

\section{Conclusion}

Horses constitute a living testimony to relations between Southeast Asia and Tibet in the longue durée, suggesting that scholars may have underestimated this dimension of the region's history. While Buddhist contacts have received a little attention, material exchanges with Tibet, especially significant for Mainland Southeast Asia, remain largely unexplored. Yunnan has acted as a kind of screen, portrayed only as a conduit to China, whereas it also led to the grasslands of the 'roof of the world'. Further research on animals in Southeast Asia, following in Peter Boomgaard's footsteps, might develop the wider implications of being located between Tibet and Australia, two of the greatest pastoral regions in the world.

Conversely, historians have tended to overestimate the impact of horses brought by sea from outside Southeast Asia. These beasts were few in number, and left little genetic imprint. Where successful new breeds appeared, they were mainly the result of selecting and managing existing animals, and not of crossbreeding with imported stock. Indeed, by the second half of the twentieth century, experts had come round to the view that importing foreign horses into the tropics, or artificial insemination from such sources, was an illusory method of ameliorating breeds. It was much more effective, if slower, to select within 'native types', and to improve feeding and management (Tempany and Grist 1958:224-226; Barlow 1990:46-47).

The arrested development of mule breeding in Southeast Asia is a final topic that requires more attention, though it is always difficult to research a negative problem. Southeast Asia is not alone in this situation, for the same question could be asked of Japan and Korea, or indeed of Britain and northern Europe. Cultural and religious prejudices against donkeys, and against hybridizing animals of different species, may well hold the key to this puzzle (Dent 1972).

24 Khoo Kay Kim, personal communication, 24 October 2001. 